\title{
SEKTOR PERTANIAN DALAM DINAMIKA TRANSFORMASI STRUKTURAL DI INDONESIA
}

\author{
Axellina Muara Setyanti* \\ Fakultas Ekonomi dan Bisnis, Universitas Brawijaya \\ Jl. MT. Haryono No.165 Malang 65300 \\ *Corresponding author: axellinamuara@ub.ac.id
}

\begin{abstract}
Indonesia is a country that has relied on the agricultural sector as an economic base for decades. On the other hand, the more developed an economy is, the higher the reserves in the service sector. Despite this declining GDP, agriculture is still very important to the Indonesian economy, even though it is 14 percent of GDP. This study analyzes structural transformation through shift-share analysis. It looks at the tendency of labor to enter the agricultural, manufacturing and service sectors using probit regression on Sakernas microdata. This study found that the service sector continues to grow and outperforms the agricultural sector both in terms of added value and employment. The results of the shift-share show shrinkagein the productivity of agricultural sector while the manufacturing and service sectors are growing. This fact proves a change in economic structure. The characteristics of the agricultural sector labor force have a higher tendency for male workers, live in rural areas, are relatively older and have fewer family members, are less educated, do not have training certification, and have no previous work experience.
\end{abstract}

Keywords: service sector, agricultural sector, manufacturing sector, probit, structural transformation

\begin{abstract}
Abstrak: Indonesia merupakan negara yang bertumpu pada sektor pertanian sebagai basis ekonomi selama puluhan tahun. Di sisi lain, semakin berkembang suatu perekonomian maka semakin tinggi pangsa sektor jasa. Meskipun pangsa PDBnya menurun, pertanian masih sangat penting bagi perekonomian Indonesia, terhitung 14 persen dari PDB. Penelitian ini menganalisis transformasi struktural melalui analisis shift-share dan melihat kecenderungan tenaga kerja memasuki sektor pertanian, industri, dan jasa menggunakan regresi probit pada data mikro SAKERNAS. Penelitian ini menemukan bahwa: 1) sektor jasa terus tumbuh dan melampaui sektor pertanian baik dari segi nilai tambah maupun total lapangan kerja. Hasil shift-share menunjukkan adanya penyusutan pada produktivitas sektor pertanian, sementara sektor industri dan jasa bertumbuh. Hal ini membuktikan adanya perubahan struktur ekonomi. 2) Karakteristik angkatan kerja sektor pertanian memiliki kecenderungan lebih tinggi pada tenaga kerja laki-laki, tinggal di pedesaan, berusia relatif lebih tua dan memiliki anggota keluarga yang lebih sedikit, berpendidikan rendah, tidak memiliki sertifikasi pelatihan, dan tidak memiliki pengalaman kerja sebelumnya.
\end{abstract}

Kata kunci: sektor jasa, sektor pertanian, sektor industri, probit, transformasi struktural

\section{PENDAHULUAN}

Hubungan antara struktur ekonomi dan tingkat pembangunan telah menjadi salah satu tema yang paling banyak dieksplorasi dalam analisis ilmu ekonomi (Panchamukhi, 1989). Proses perubahan struktural yang saling terkait yang mengikuti atau diikuti oleh perkembangan ekonomi, sering disebut sebagai transformasi struktural. Istilah transformasi atau perubahan 
struktural dalam perekonomian juga sering digunakan untuk menjelaskan transformasi komposisi produksi, lapangan kerja, permintaan dan perdagangan, yang muncul seiring dengan perkembangan suatu negara (Doyle, 1997; Marjanović, 2015). Dalam pendekatan makroekonomi, pembangunan ekonomi dipersepsikan sebagai sekumpulan proses transformasi struktural jangka panjang yang bergantung dan mengikuti proses pertumbuhan. Karakteristik utama dari pendekatan transformasi ekonomi misalnya perluasan fenomena ekonomi seperti industrialisasi atau urbanisasi, yang oleh Kuznets disebut sebagai pertumbuhan ekonomi modern (Marjanović, 2015).

Di negara berkembang, transformasi struktural sebagian besar dimulai pada tahun 1900-an. Prosesnya ada yang terjadi secara bertahap, bahkan tiba-tiba dan tidak selalu sama dalam beberapa kasus. Kecenderungan umumnya, sebagian besarterjadi melalui perubahan sektor agraris ke campuran agraria, industri, dan sektor jasa (Divanbeigi et al., 2016). Proses transformasi struktural di negaranegara berkembang biasanya berbeda dari proses yang dialami oleh negara-negara maju, utamanya dalam dua hal: hubungan antara perubahan output sektoral dan perubahan PDB per kapita, serta tingkat kontribusi output sektoral pada PDB per kapita (Bah, 2009).

Indonesia merupakan negara yang menjadikan sektor pertanian sebagai basis ekonomi selama puluhan tahun. Total luas tanah negara yang digunakan untuk produksi pertanian setara dengan $32 \%$ dari total luas lahan. Meskipun pangsa PDBnya menurun, pertanian masih sangat penting bagi perekonomian Indonesia, terhitung 14\% dari PDB. Di Indonesia, usahatani keluarga kecil umumnya dilakukan di petak-petak sederhana dengan luas rata-rata 0,6 hektar. Rumah tangga petani rata-rata terdiri dari 5 sampai 6 anggota rumah tangga dengan kepala rumah tangga memiliki tingkat pendidikan rata-rata 6 tahun (Food and Agricultural Organization, 2018). Dengan pertumbuhan PDB tahunan rata-rata 5$6 \%$, Indonesia telah menjadi ekonomi terbesar di Asia Tenggara selama dekade terakhir (Food and Agricultural Organization, 2018).

Meskipun pertanian tetap menjadi penyedia lapangan kerja terbesar di banyak negara, termasuk Indonesia, diskusi tentang transformasi struktural tidak dapat diabaikan. Transformasi pertanian kemungkinan akan berlanjut sesuai dengan histori yang telah ada, meskipun laju dan arah perubahan akan diselingi oleh tantangan dan peluang baru yang muncul, misalnya terkait dengan tekanan lingkungan, ketidakstabilan pasar, atau terobosan teknologi di masa yang akan datang (Briones \& Felipe, 2013).

Banyak literatur menganalisis faktorfaktor yang menyebabkan suatu perekonomian bergeser ke arah jasa. Yang pertama adalah pandangan tradisional yang dikemukakan oleh Fisher (1935) dan Clark (1940) yang menyatakan bahwa proporsi sektor jasa meningkat seiring dengan perubahan struktur konsumsi dari barang ke jasa sebagai konsekuensi dari pertumbuhan pendapatan. Dengan kata lain, sektor jasa meningkat seiring dengan naiknya tingkat pendapatan karena elastisitas permintaan barang kurang dari 1 (Hukum Engel), tetapi permintaan jasa lebih besar dari satu (Schettkat dan Yocarini, 2006).

Banyaknya penyerapan kerja di bidang pertanian, yang seringkali ditandai dengan surplus tenaga kerja dan pengangguran terselubung, menyiratkan bahwa pertanian belum memberikan sumber pendapatan optimum bagi mereka yang kurang terampil, lebih tua, dan sudah tidak lagi produktif (Tocco et al., 2013). Selain itu, terdapat faktor-faktor yang memengaruhi keputusan keluar dari pertanian. Teori human capital dan life-cycle merupakan penjelasan yang paling berpengaruh untuk memahami mobilitas tenaga kerja pertanian ke sektor lain (Huffman, 1980; Rizov dan Swinnen, 2004; Tocco et al., 2013).

Seperti dalam hipotesis Bah (2009), pergeseran kontribusi output sektoral merupakan hal yang pasti dilalui negara maju selama proses pembangunan yang panjang. Meskipun kecepatan transformasi mungkin berbeda di setiap negara, semua menghadirkan pola serupa. Seiring dengan peningkatan PDB, kontribusi sektor pertanian menurun, sektor industri pada awalnya meningkat dan kemudian menurun, sedangkan bagian sektor jasa terus meningkat.

Tujuan penelitian ini adalah untuk mengetahui, 1) transformasi struktural di Indonesia melalui pertumbuhan produktivitas agregat sektor pertanian, industri, dan jasa, 2) kecenderungan karakteristik individu tenaga 
kerja di sektor pertanian, industri, dan jasa di Indonesia.

\section{METODE PENELITIAN}

Untuk menangkap fenomena transformasi struktural pada tujuan penelitian yang pertama, penulis menggunakan data World Development Indicator (WDI) yang dirilis oleh World Bank. Transformasi ini akan dijelaskan secara deskriptif dari analisis data makro WDI, serta dapat dikembangkan melalui perhitungan shiftshare. Analisis shift-share berguna untuk mengetahui aggregate productivity growth pada sektor pertanian, industri, dan jasa.

Untuk tujuan penelitian yang kedua yaitu mengetahui karakteristik individu pada sektor pertanian, industri, dan jasa digunakan data Survei Angkatan Kerja Nasional (Sakernas) 2018 oleh Badan Pusat Statistik (2018). Data Sakernas menangkap informasi mengenai keadaan umum ketenagakerjaan pada tingkat individu. Data-data yang telah dihimpun dianalisis menggunakan Regresi Probit. Model regresi dalam penelitian ini adalah:

$$
\begin{aligned}
Y i= & \propto+b_{1} X_{1 i}+b_{2} X_{2 i}+b_{3} X_{3 i}+b_{4} X_{4 i}+b_{5} X_{5 i} \\
& +b_{6} X_{6 i}+b_{7} X_{7 i}+b_{8} X_{8 i}+e
\end{aligned}
$$

\begin{tabular}{|c|c|}
\hline & $\begin{aligned}= & \text { Bekerja pada sektor pertanian } \\
& (\text { Dummy bekerja pada sektor } \\
& \text { pertanian }=1 \text {; lainnya }=0)\end{aligned}$ \\
\hline & $\begin{array}{l}\text { Jenis Kelamin (Dummy } \\
\text { laki=1; perempuan }=0)\end{array}$ \\
\hline & Usia (tahun) \\
\hline & Usiakuadrat \\
\hline & Jumlah anggota keluarga (orang) \\
\hline & $\begin{array}{l}\text { Pendidikan/lama bersekolah } \\
\text { (tahun) }\end{array}$ \\
\hline & $\begin{aligned} & \text { Sertifikasi } \quad(\text { Dummy memilik } \\
& \text { sertifikat pelatihan }=1 ; \text { tidak }=0)\end{aligned}$ \\
\hline & 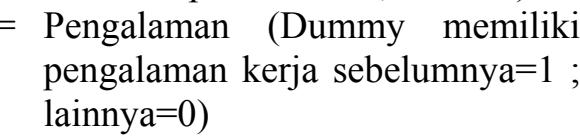 \\
\hline & $\begin{aligned} & \text { Desa (Dummy Bertempat tingga } \\
& \text { di desa }=1 ; \text { di kota }=0 \text { ) }\end{aligned}$ \\
\hline & Konstanta atau intersep \\
\hline$b_{2}, b_{3}=$ & Koefisien atau parameter \\
\hline
\end{tabular}

dimana:
Dengan analisis regresi probit akan dihasilkan skor $\mathrm{Z}$ yang merupakan suatu variabel kontinyu yang tidak teramati (laten) karena merupakan suatu "kecenderungan" munculnya sebuah kejadian. Jadi misalnya data yang diamati dalam penelitan ini adalah bekerja pada sektor n (kode 1) dan bekerja pada sektor lainnya (kode 0 ), nilai $\mathrm{Z}$ menunjukkan kecenderungan atau probabilitas untuk bekerja pada sektor $\mathrm{n}$. Dalam kasus ini $\mathrm{Z}$ merupakan suatu kecenderungan tenaga kerja untuk bekerja pada sektor $\mathrm{n}$. Semakin besar nilai $\mathrm{Z}$ semakin besar kecenderungan individu untuk bekerja pada sektor $\mathrm{n}$ tersebut.

\section{HASIL DAN PEMBAHASAN}

\section{Gambaran Umum Penyerapan Tenaga Kerja dan Nilai Tambah Sektor Pertanian, Industri, dan Jasa}

Dalam teori ekonomi pembangunan, ungkapan pergeseran atau transformasi struktural secara umum mengacu pada perubahan komposisi sektoral PDB dari sektor tradisional ke sektor modern yang lebih produktif (Szirmai, 2012; Islam dan Iversen, 2018). Berdasarkan model pembangunan dua sektor Arthur Lewis, perekonomian yang berkembang terdiri dari dua sektor yaitu sektor tradisional dan sektor modern. Sektor tradisional dicirikan oleh sektor pedesaan subsisten yang kelebihan penduduk dan dicirikan oleh produktivitas tenaga kerja marjinal rendah atau nol. Di sisi lain, sektor perkotaan modern merupakan sektor yang memiliki tingkat produktivitas yang tinggi dan merupakan tempat menampung tenaga kerja yang sedikit demi sedikit berpindah dari sektor tradisional (Romli et al., 2016). Berbeda dengan Lewis, Kuznets membedakan dua fase transformasi struktural. Pada awal proses pembangunan, perekonomian mengalokasikan sebagian besar sumber dayanya untuk sektor pertanian. Seiring perkembangan ekonomi, sumber daya dialokasikan kembali dari pertanian ke industri dan jasa. Ini adalah fase pertama transformasi struktural. Pada fase kedua, sumber daya dialokasikan kembali dari pertanian dan industri ke jasa (Bah, 2009). 
Setyanti, A. M. :Sektor Pertanian Dalam Dinamika Transformasi...

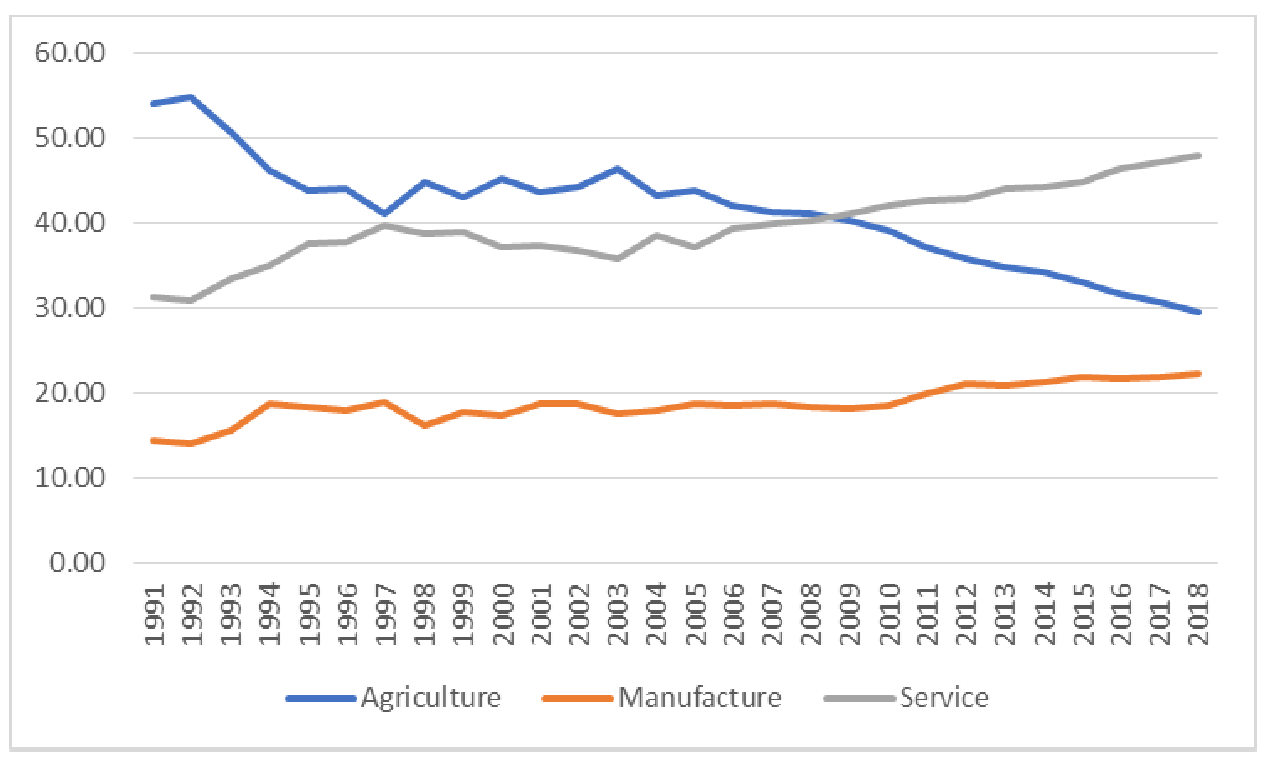

Gambar 1. Penyerapan tenaga kerja berdasarkan sektor (persentase dari total penyerapan) Sumber: World Bank (Diolah), 2020

Semakin berkembang perekonomian, semakin tinggi pangsa sektor jasa. Secara umum dapat diamati bahwa suatu perekonomian cenderung beralih ke jasa seiring dengan peningkatan pendapatan per kapita. Jadi, perubahan struktural dalam perekonomian merupakan proses yang tak terelakkan dari pertumbuhan ekonomi (OECD, 2000; Kim, 2006; Witt dan Gross, 2020). Pada awal abad ke-21, semua negara industri tinggi telah menjadi 'ekonomi jasa', setidaknya jika diukur dari segi pangsa tenaga kerja yang dipekerjakan di industri jasa (Schettkat dan Yocarini, 2006).

Amerika Serikat yang memiliki sektor jasa terbesar di dunia telah menunjukkan pertumbuhan yang dinamis di tahun 1990-an dengan didukung oleh industri layanan yang inovatif dan menggunakan IT, seperti keuangan, perdagangan ritel, komunikasi dan sebagainya, adalah salah satu buktinya. Di Korea, sektor jasa telah tumbuh dan mampu berkontribusi $56 \%$ dari total nilai tambah ekonomi dan $65 \%$ dari lapangan kerja pada tahun 2005. Karena perubahan dalam struktur ekonomi, permintaan akan jasa sebagai input perantara, seperti untuk bisnis jasa (keuangan, asuransi, jasa hukum, jasa akuntansi, dan sebagainya), telah berkembang. Pada saat yang sama, pengeluaran rumah tangga untuk layanan, seperti perjalanan, pendidikan dan layanan budaya, meningkat pesat (Kim, 2006).
Perluasan lapangan kerja industri jasa mungkin disebabkan oleh: pergeseran dalam struktur permintaan akhir dari barang ke jasa; perubahan dalam pembagian kerja antarindustri, mendukung peningkatan aktivitas layanan khusus; atau perbedaan produktivitas antar industri (Schettkat dan Yocarini, 2006). Untuk memahami kondisi pergeseran sektoral di Indonesia, grafik di bawah ini menunjukkan pangsa lapangan kerja dan produktivitas sektoral selama periode 1991-2018.

Gambar 1 menjelaskan kondisi penyerapan tenaga kerja sektor pertanian, industri, dan jasa dalam kurun waktu 3 dekade terakhir. Sektor industri disertakan sebagai perbandingan karena pergeseran sektor umumnya terjadi melalui fase sektor primer sekunder - tersier atau pertanian - industri jasa. Sejak lama sektor pertanian menjadi sektor dengan penyerapan tenaga kerja tertinggi namun trennya cenderung mengalami penurunan. Sampai pada tahun 2009 sektor jasa dengan penyerapan tenaga kerja $41,25 \%$ mengungguli sektor pertanian yang menyerap $40,45 \%$ tenaga kerja. Pada tahun-tahun berikutnya, penyerapan tenaga kerja sektor pertanian terus mengalami penurunan, sebaliknya pada sektor jasa penyerapannya terus meningkat. 
Setyanti, A. M. :Sektor Pertanian Dalam Dinamika Transformasi...

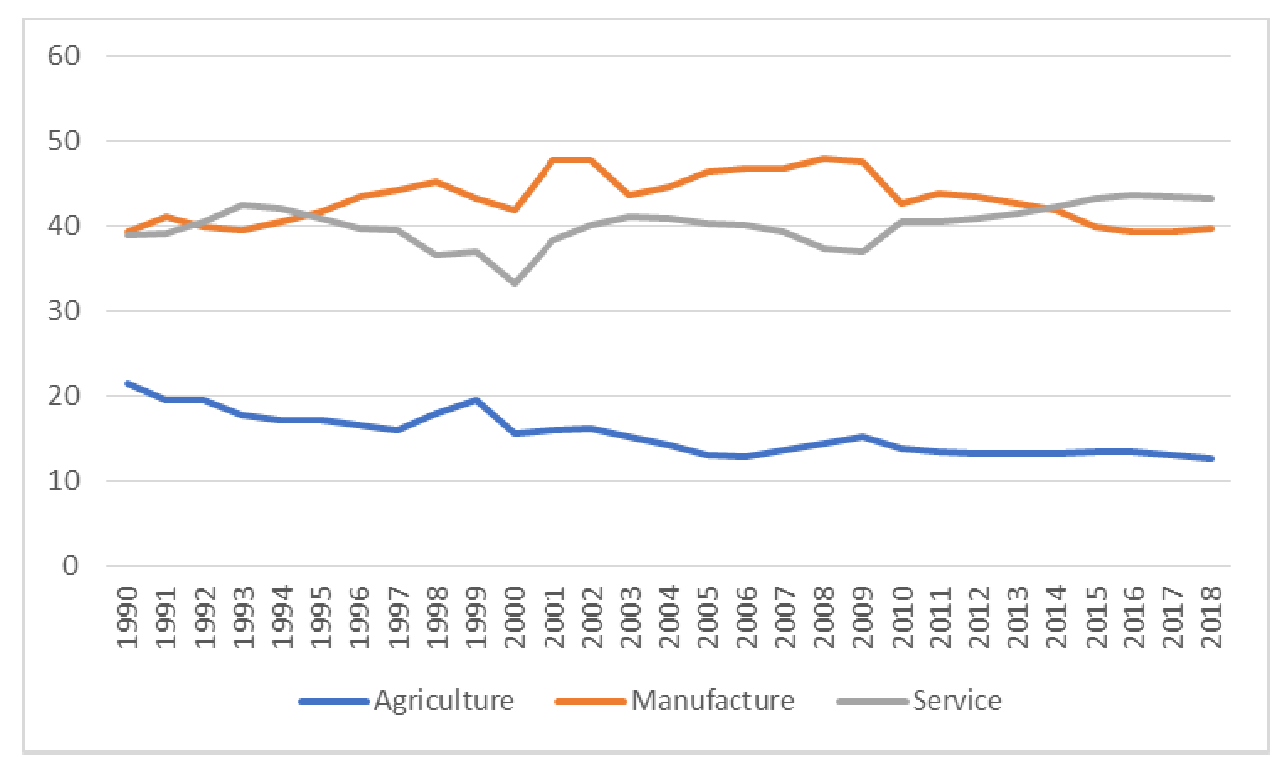

Gambar 2. Nilai tambah sektor (persentase kontribusi pada GDP) Sumber: World Bank (Diolah), 2020

Tetapi jasa tidak mendapatkan semua tenaga kerjanya dari mereka yang meninggalkan sektor pertanian dan industri; Pertumbuhan lapangan kerja sebagian besar berasal dari perluasan angkatan kerja, khususnya peningkatan partisipasi perempuan. Namun, penurunan jumlah petani bukan satusatunya masalah di sektor pertanian. Sektor ini menghadapi masalah pekerja yang menua. Ketertarikan generasi muda terhadap pertanian masih kurang sehingga petani didominasi oleh usia lanjut (Anandita dan Patria, 2016).

Hal ini juga menunjukkan bahwa telah terjadi permasalahan ketimpangan struktural sebagai akibat proses industrialisasi yang ditempuh selama empat dekade terakhir (mulai awal tahun 1970-an). Perubahan struktural dalam output perekonomian dari sektor pertanian ke sektor industri tidak diikuti oleh perubahan struktur ketenagakerjaan (Amir, 2015). Asian Development Bank(2013) mengklasifikasikan negara-negara di dunia yang telah berhasil melakukan industrialisasi dan yang belum dalam dua kategori, yaitu dilihat dari sisi output dan ketenagakerjaan. Indonesia pada sampai dengan tahun 2013 masuk kepada kategori negara low middleincome countries yang telah berhasil melakukan industrialisasi dari sisi output tetapi belum berhasil dari sisi ketenagakerjaan. Sekali lagi, peran output sektor pertanian sudah menurun drastis tetapi sektor ini masih 'dihuni' oleh rumah tangga atau tenaga kerja yang cukup banyak.

Maka dari itu, selain tingkat penyerapan tenaga kerja, penting untuk melihat tren produktivitas output sektor tersebut selama periode yang sama. Nilai tambah mencerminkan nilai yang dihasilkan oleh produksi barang dan jasa, dan diukur sebagai nilai keluaran dikurangi nilai konsumsi antara. Nilai tambah juga mewakili pendapatan yang tersedia untuk kontribusi tenaga kerja dan modal untuk proses produksi. Nilai tambah aktivitas menunjukkan nilai tambah yang diciptakan oleh berbagai sektor.

Di Indonesia, sektor jasa terus tumbuh hingga mencapai $43 \%$ dari total nilai tambah perekonomian dan $48 \%$ dari lapangan kerja pada tahun 2018, melampaui pertanian dengan nilai tambah $1 \%$ dan $29 \%$ dari total lapangan kerja pada tahun yang sama (Gambar 2). Hal ini menunjukkan adanya perubahan struktur ekonomi. Perubahan struktural yang berasal dari jasa mungkin mendukung sektor-sektor yang cenderung memiliki produktivitas lebih tinggi, lebih intensif teknologi atau dengan lebih banyak potensi peningkatan, yang mengarah pada pertumbuhan yang dipimpin jasa. Untuk lebih memahami pertumbuhan setiap sektor, selanjutnya digunakan analisis shift-share. 
Transformasi Struktural di Indonesia

Teknik analisis "shift-share" dalam bagian ini digunakan untuk menguji pergeseran sektoral pada pertumbuhan produktivitas agregat. Analisis shift-share menunjukkan bagaimana pertumbuhan produktivitas tenaga kerja agregat dikaitkan dengan perbedaan pertumbuhan produktivitas tenaga kerja di masing-masing sektor dan realokasi tenaga kerja antar sektor.

Pendekatan ini membedakan pertumbuhan produktivitas tenaga kerja agregat selama periode waktu tertentu menjadi "within effect" (pertumbuhan produktivitas tenaga kerja dalam setiap industri), dan "shift effect" atau "efek perubahan struktural" yang mengindikasikan adanya pertumbuhan produktivitas tenaga kerja karena pekerjaan bergeser ke sektor yang lebih produktif. Dekomposisi pertumbuhan produktivitas dinyatakan dalam persamaan berikut:

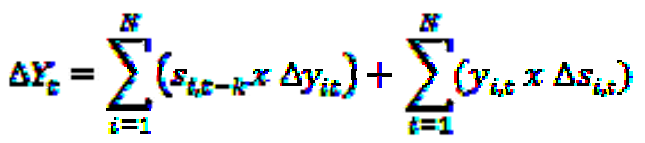

Persamaan tersebut menunjukkan bahwa pertumbuhan produktivitas tenaga kerja secara keseluruhan dalam suatu perekonomian terbagi menjadi dua komponen. Yang pertama adalah "within effect", yang merupakan pangsa lapangan kerja di setiap sektor $\left(\mathrm{S}_{\mathrm{i}, \mathrm{t}}\right)$ dikalikan dengan kontribusi dari pertumbuhan produktivitas dalam masing-masing sektor $\left(\Delta \mathrm{y}_{\mathrm{i}, \mathrm{t}}\right)$. Yang kedua adalah "shift effect" atau kontribusi dari realokasi tenaga kerja di berbagai sektor. Shift effect diperoleh dari perubahan pangsa lapangan kerja dikalikan dengan tingkat produktivitas pada akhir periode waktu lintas sektor.

Kontribusi setiap sektor dalam pengaruh perubahan struktural dapat berupa positif atau negatif, tergantung pada apakah suatu sektor berkembang atau menyusut. Ketika kontribusi dari masing-masing sektor digabungkan, istilah perubahan struktural menjadi negatif, menurunkan pertumbuhan produktivitas di seluruh ekonomi, jika tenaga kerja yang dipindahkan dari sektor pertumbuhan produktivitas tinggi pindah ke sektor pertumbuhan produktivitas rendah.

Dengan mengadopsi teknik yang digunakan Lee dan McKibbin (2018) dan Isaksson (2010) untuk menganalisis dekomposisi pertumbuhan produktivitas, kami menggunakan data nilai tambah per pekerja sebagai proksi produktivitas dan persentase lapangan kerja sektor dari total lapangan kerja untuk menunjukkan pangsa lapangan kerja. Semua data yang digunakan berasal dari World Development Indicator oleh World Bank.

Produktivitas tenaga kerja digunakan untuk menilai kemampuan ekonomi suatu negara untuk menciptakan dan mempertahankan peluang kerja yang layak dengan remunerasi yang adil dan setara. Peningkatan produktivitas yang diperoleh melalui investasi, perdagangan, kemajuan teknologi, atau perubahan organisasi kerja dapat meningkatkan perlindungan sosial dan mengurangi kemiskinan, yang pada akhirnya mengurangi pekerjaan rentan dan pekerja miskin. Peningkatan produktivitas tidak menjamin peningkatan perlindungan sosial dan pengurangan kemiskinan, namun tanpanya, peningkatan tersebut tidak mungkin terjadi.

Nilai tambah pertanian per pekerja adalah ukuran produktivitas pertanian. Nilai tambah dalam pertanian mengukur output sektor pertanian dikurangi nilai input antara. Pertanian terdiri dari nilai tambah dari kehutanan, perburuan, dan penangkapan ikan serta budidaya tanaman dan produksi ternak. Data dalam dolar AS 2010 konstan (World Bank, 2018). Begitu pula dengan definisi produktivitas sektor jasa. Tabel 1 menyajikan hasil analisis shift-share sektor pertanian dan jasa dengan menggunakan data tahun 19902018.

Tabel 1. Dekomposisi pertumbuhan produktivitas 1990-2018

\begin{tabular}{llrr}
\hline Sektor & Total & Within Effect & Shift Effect \\
\hline Pertanian & $-57.107,75$ & $3.511,03$ & $-60.618,78$ \\
Industri & $105.194,44$ & $2.309,08$ & $102.885,35$ \\
Jasa & $113.547,77$ & $6.041,75$ & $107.506,01$ \\
\hline
\end{tabular}

Sumber: World Bank (Diolah), 2020 
Setyanti, A. M. :Sektor Pertanian Dalam Dinamika Transformasi...

Tabel 2. Analisis probit karakteristik tenaga kerja pada sektor

\begin{tabular}{lrrrrrr} 
& \multicolumn{2}{c}{ Pertanian } & \multicolumn{2}{c}{ Industri } & \multicolumn{2}{c}{ Jasa } \\
\cline { 2 - 7 } Jenis kelamin & Coef & $\mathrm{P}>|\mathrm{z}|$ & \multicolumn{1}{c}{ Coef } & $\mathrm{P}>|\mathrm{z}|$ & \multicolumn{1}{c}{ Coef } & $\mathrm{P}>|\mathrm{z}|$ \\
Usia & $0,186^{*}$ & 0,000 & $-0,182^{*}$ & 0,000 & $0,396^{*}$ & 0,000 \\
Usia $^{2}$ & $-0,013^{*}$ & 0,000 & $-0,006^{*}$ & 0,000 & $0,005^{*}$ & 0,000 \\
Anggota Rumah Tangga & $0,0003^{*}$ & 0,000 & 0,00001 & 0,605 & $-0,0001^{*}$ & 0,000 \\
Pendidikan & $-0,005^{*}$ & 0,001 & $-0,005^{*}$ & 0,002 & $-0,006^{*}$ & 0,000 \\
Sertifikasi & $-0,027^{*}$ & 0,000 & $0,006^{*}$ & 0,000 & $0,015^{*}$ & 0,000 \\
Pengalaman & $-0,780^{*}$ & 0,000 & $-0,207^{*}$ & 0,000 & $0,534^{*}$ & 0,000 \\
Desa & $-0,228^{*}$ & 0,000 & $0,180^{*}$ & 0,000 & $0,041^{*}$ & 0,000 \\
Kontanta & $1,223^{*}$ & 0,000 & $-0,245^{*}$ & 0,000 & $-0,044^{*}$ & 0,000 \\
Observasi & $-0,623$ & 0,000 & $-0,918^{*}$ & 0,000 & $-0,571$ & 0,000 \\
LR chi ${ }^{2}$ & 288.196 & & 288.196 & & 228.196 & \\
Prob>chi ${ }^{2}$ & 82525,33 & & 4013,40 & & 23282,29 & \\
Pseudo R ${ }^{2}$ & 0,0000 & & 0,0000 & & 0,0000 & \\
\hline
\end{tabular}

Keterangan: *signifikan pada $\alpha 0,01$

Sumber: Sakernas 2018 Diolah

Hasil negatif dari perubahan struktural dan pengaruh total pertanian menunjukkan menyusutnya sektor ini sementara di sisi lain sektor industri dan jasa tumbuh. Pertumbuhan jasa itu sendiri terlihat lebih besar dari pada industri. Pentingnya sektor jasa berasal dari tren pelayanan, di mana jasa memiliki kontribusi besar terhadap keluaran, lapangan kerja dan investasi dan relevansi yang meningkat dalam perdagangan internasional, di mana ia tumbuh lebih dari sekedar barang, lebih tangguh, dan lebih banyak di negara berkembang. Selain itu, jasa dapat memberikan masukan perantara untuk semua kegiatan ekonomi, digabungkan dengan barang, dan dikembangkan di dalam perusahaan industri. Melalui semua efek ini, sektor jasa mendorong efisiensi, efektivitas, produktivitas dan kapasitas produksi dan ekspor, terutama di usaha mikro, kecil dan menengah. Seperti dalam Lee dan McKibbin (2018) perubahan struktural telah memberikan kontribusi yang signifikan terhadap pertumbuhan produktivitas tenaga kerja secara keseluruhan di beberapa negara Asia termasuk Hong Kong, Cina; Indonesia; dan Thailand. Seperti yang dikemukakan McMillan dan Rodrik (2011) bahwa Asia luar biasa tidak begitu banyak dalam pertumbuhan produktivitas dalam sektor individu, tetapi dalam pola perubahan struktural yang luas.

\section{Kecenderungan Karakteristik Individu Tenaga Kerja di Sektor Pertanian, Industri, dan Jasa}

Sektor pertanian yang pada awal pembangunan nasional dijadikan sebagai lapangan usaha utama penduduk berangsur-angsur menurun dengan digantikannya oleh sektor industri dan jasa. Inilah yang disebut dengan transformasi kesempatan kerja dari sektor primer (pertanian) ke sektor sekunder (industri) dan tersier (jasa). Namun demikian, transformasi ini belumlah ideal seperti yang terjadi di banyak negara maju, yaitu pergeseran dari sektor pertanian ke sektor industri. Penurunan kegiatan ekonomi sektor pertanian di Indonesia justru diikuti dengan meningkatnya persentase penduduk secara signifikan di sektor jasa. Ini berarti kegiatan ekonomi tradisional nonpertanian menjadi marak di perdesaan, begitu juga sektor informal di perkotaan tumbuh dengan cepat.

Hasil estimasi regresi probit di atas menunjukkan bahwa hampir seluruh variabel independen berpengaruh secara signifikan dalam memengaruhi kecenderungan seseorang untuk bekerja, baik pada sektor pertanian, industri, maupun jasa. Dari segi pendidikan, ditemukan bahwa semakin tinggi pendidikan/lama sekolah dari tenaga kerja, semakin kecil kecenderungan untuk bekerja pada sektor pertanian, ditunjukkan oleh arah koefisien yang negatif.Probabilitas seseorang untuk bekerja pada sektor pertanian menurun 
0,027 kali dengan meningkatnya pendidikan. Sebaliknya, terdapat kecenderungan yang positif pada sektor industri dan jasa, ditunjukkan oleh koefisien regresi masingmasing 0,006 dan 0,015. Kecenderungan untuk memilih sektor jasa ditemukan lebih besar dibandingkan dengan sektor industri.

Begitu pula pada tenaga kerja yang memiliki sertifikat pelatihan, memiliki kecenderungan yang lebih tinggi untuk bekerja pada sektor jasa, terlihat dari koefisien sektor pertanian $-0,780$ yang dapat diinterpretasikan bahwa probabilitas seseorang yang memiliki sertifikasi keterampilan akan menurun 0,780 kali untuk memasuki sektor pertanian dibandingkan sektor lainnya, lalu probabilitas juga ditemukan menurun 0,207 kali untuk memasuki sektor industri. Dari segi pengalaman bekerja, tenaga kerja yang telah memiliki pengalaman bekerja sebelumnya, probabilitas untuk bekerja pada sektor industri dan jasa meningkat dibandingkan sektor pertanian, ditunjukkan oleh koefisien regresi masing-masing 0,180 dan 0,041 . Terakhir, seseorang yang tinggal di desa ditemukan memiliki probabilitas paling tinggi untuk bekerja di sektor pertanian.

Sebagaimana telah diungkap, transformasi ekonomi yang terjadi di Indonesia bukanlah transformasi yang ideal. Ini berdampak pada sistem ekonomi yang dihasilkan. Transformasi ideal akan mengarah pada sistem ekonomi formal (industri), sedangkan transformasi tidak ideal cenderung menuju ke sistem ekonomi informal (jasa). Pergeseran sektor ideal, yakni dari pertanian menuju industri dan akhirnya menuju sektor jasa setelah terjadinya deindustrialisasi, tidak sepenuhnya terjadi di Indonesia. Meskipun berbagai strategi pembangunan telah diterapkan, ada kecenderungan proses transformasi tidak mengikuti pola yang telah dialami oleh negara-negara maju. Proporsi pekerja yang bekerja di sektor pertanian cenderung menurun, tetapi secara absolut sektor ini menyerap lebih dari separuh pekerja. Sektor industri yang seharusnya menyerap sebagian besar pekerja, hanya mampu menyerap sebagian kecil saja. Sektor jasa yang seharusnya berkembang setelah sektor industri, justru meningkat lebih awal, bahkan menyerap banyak tenaga kerja. Prospektif di sektor jasa ini semakin meneguhkan betapa sektor informal secara makro sangat berperan dalam pembangunan ekonomi di Indonesia (Pitoyo, 2007).

\section{KESIMPULAN}

Berdasarkan hasil pembahasan, penelitian ini menemukan kecenderungan penurunan pada penyerapan tenaga kerja sektor pertanian, dan sebaliknya pada sektor jasa penyerapannya cenderung meningkat. Dari segi nilai tambah, sektor jasa terus tumbuh hingga mencapai 43 persen dari total nilai tambah perekonomian dan 48 persen dari lapangan kerja pada tahun 2018, melampaui pertanian dengan nilai tambah 12 persen dan 29 persen dari total lapangan kerja pada tahun yang sama. Selain itu, ditemukan bahwa tenaga kerja sektor pertanian memiliki kecenderungan lebih tinggi pada tenaga kerja laki-laki, tinggal di pedesaan, berusia relatif lebih tua dan memiliki anggota keluarga yang lebih sedikit, berpendidikan rendah, tidak memiliki sertifikasi pelatihan, dan tidak memiliki pengalaman kerja sebelumnya.

Transformasi struktural adalah hal yang tidak dapat dihindari, oleh karena itu fokus baru yang harus ditetapkan adalah upaya peningkatan produktivitas di sektor pertanian. Seiring berjalannya waktu, proses alami urbanisasi, dan transformasi ke sektor-sektor non pertanian harus terus diimbangi dengan meningkatnya produktivitas pertanian sebagai penghasil pangan sebagian besar penduduk, bahkan yang tidak terlibat dalam sektor tersebut. Sektor industri dan jasa juga dapat dikembangkan untuk mendorong sektor pertanian, misalnya agri-food industry yang lebih berdaya saing dan bernilai tambah.

\section{DAFTAR PUSTAKA}

Amir, H. (2015). Sektor Pertanian: Perlu Upaya Akselerasi Pertumbuhan. Jakarta: Kementerian Keuangan.

Anandita, Della Ayu \& Patria, K.Z.(2016). Agriculture challenges: Decline of farmers and farmland (study from Indonesian Family Life Survey). Jurnal Ilmu Ekonomi dan Pembangunan, 16(1), 48-53. 
Setyanti, A. M. :Sektor Pertanian Dalam Dinamika Transformasi...

Asian Development Bank. (2013). Asia's Economic Transformation Where to, How, and How Fast?Manila: ADB.

Badan Pusat Statistik (BPS). (2018). Survei Angkatan Kerja Nasional. Jakarta: Badan Pusat Statistik

Bah, E.H.(2009). Structural transformation in developed and developing countries.Proceedings of the German Development Economics Conference.

Briones, R.,\& Felipe, J.(2013). Agriculture and structural transformation in developing Asia.ADB Economics Working Paper Series, 363. Retrieved from https://www.adb.org/sites/default/files/pu blication/30380/ewp-363.pdf.

Clark, C. (1940). The Conditions of Economic Progress. London: MacMillan \& Co. Ltd.

Divanbeigi, R., Paustian, N., \& Loayza, N.(2016). Structural transformation of the agricultural sector: A Primer.World Bank Research and Policy Briefs, 104231.

Doyle, E. (1997). Structural change in Ireland. Journal of Economic Studies, 24, 58-68.

Fisher, A.G.B. (1935). The Clash of Progress and Security.London: MacMillan \& Co. Ltd.

Food and Agricultural Organization.(2018). Small family farms country factsheet. Retrieved from http://www.fao.org/fami farming/detail/en/c/1115197/.

Huffman, W.E. (1980). Farm and off-farm work decisions: The role of human capitalThe Review of Economics and Statistics, 62(1), 14-23.

Isaksson, A. (2010). Structural change and productivity growth: a review with implications for developing countries.UNIDO Working Paper, 08. Retrieved fromhttps://www.unido.org/api/opentext/ documents/download/10081102/unidofile-10081102.

Islam, S. N., \& Iversen, K. (2018). From "structural change" to "transformative change": Rationale and implications. United Nations Working Paper, 155. Retrieved fromhttps://www.un.org/esa/desa/papers/ 2018/wp155_2018.pdf

Kim, H.J. (2006). The Shift to the Service Economy: Causes and Effects. Washington: Institute for Monetary and Economic Research.

Lee, J.W, \& McKibbin, W. (2018).Service sector productivity and economic growth in Asia. Economic Modelling, 74, 247263.

Marjanović, V. (2015). Structural changes and structural transformation in a modern development economy. Economic Themes, 53(1), 63-82.

McMillan, M. S., \& Rodrik, D.(2011). Globalization, structural change, and productivity growth.NBER Working Paper, 17143. Retrieved from https:// www.nber.org/papers/w17143.

OECD. (2000). The Service Economy. Paris: Science Technology Industry Business and Industry Policy Forum Series.

Panchamukhi, V. R. (1989). International agricultural trade: Some policy issues. Indian Journal of Agricultural Economics, 44, 399-403.

Pitoyo, A.J. (2007). Dinamika sektor informal di Indonesia prospek, perkembangan, dan kedudukannya dalam sistem ekonomi makro. Populasi, 18(2), 129146.

Rizov, M. \& Swinnen, J.F.M. (2004).Humancapital, market imperfections, and labor reallocation in transition, Journal of Comparative Economics,32(4), 745- 774. 
Setyanti, A. M. :Sektor Pertanian Dalam Dinamika Transformasi...

Romli, M. S., Hutagaol, M. P., \& Priyarsono,D.S. (2016). Transformasi struktural: $\quad$ Faktor-faktor dan pengaruhnya terhadap disparitas pendapatan di Madura. Jurnal Ekonomi dan Kebijakan Pembangunan, 5(1), 2544.

Schettkat, R., \& Yocarini, L. (2006). The shift to services employment: A review of the literature. Structural change and economic dynamics, 17(2), 127-147.

Szirmai, A. (2012). Industrialisation as an engine of growth in developing countries, 1950-2005. Structural change and economic dynamics, 23(4), 406-420.

Tocco, B., Davidova, S., \&Bailey, A.(2012). Key issues in agricultural labour markets: A review of major studies and project reports on agriculture and rural labour markets. Factor Markets
Working Paper, 20. Retrieved from http:// aei.pitt. edu/58523/1/Factor_Markets_20. pdf.

Witt, U., \& Gross, C. (2020). The rise of the "service economy" in the second half of the twentieth century and its energetic contingencies. Journal of Evolutionary Economics, 30, 231-246.

World Bank. (2018). Definisi nilai tambah (Value Added).Retrieved from https://da tacatalog.worldbank.org/search?query= $\% 20$ services-value-added-current-us- 0 .

World Bank. (2020). World development indicators.Retrieved from https://data bank.worldbank.org/source/worlddevelopment-indicators. 